Ayuningsari, I. • S. Rosniawaty $\cdot$ Y. Maxiselly $\cdot$ I.R.D. Anjarsari

\title{
Pengaruh konsentrasi Benzyl Amino Purine terhadap pertumbuhan beberapa klon tanaman teh (Camellia sinensis L.) O. Kuntze) belum menghasilkan di dataran rendah
}

\section{The effect of Benzyl Amino Purine concentration on growth of some clone immature tea plant (Camellia sinensis L.) O. Kuntze) in the lowland}

Diterima : 17 Agustus 2017/Disetujui : 25 Agustus 2017 / Dipublikasikan : 31 Agustus 2017 CDepartment of Crop Science, Padjadjaran University

\begin{abstract}
The growth of the tea plant (Camellia sinensis L.) O. Kuntze) grown in lowland is affected by genetic and environment factor. The uses of clone as the genetic factor and plant growth regulator as exogenous hormone application are expected to be promoting the growth and development of immature tea plants grown in the lowland. The experimental design used Split Plot Design (SPD) with two factors. Clone as a main plot consisted of GMB 4, GMB 7, GMB 9, and GMB 11. Benzyl Amino Purine (BAP) concentration as a subplot consisted of 0 ppm, 30 ppm, 60 ppm, 90 ppm , and 120 ppm. There was interaction between clones and BAP concentration on stem diameter at 4 WAT. The $60 \mathrm{ppm}$ of concentration BAP indicated could promote stem diameter and number of buds in 2 WAT. The clone of GMB 4 was the highest in number of buds.
\end{abstract}

Keywords: Immature tea plant - GMB clone • BAP

Sari Pertumbuhan tanaman teh (Camellia sinensis L.) O. Kuntze) di dataran rendah dipengaruhi oleh faktor genetik dan faktor lingkungan. Faktor genetik berupa klon unggul dan faktor lingkungan berupa aplikasi hormon eksogen diharapkan mampu meningkatkan pertumbuhan tanaman teh belum menghasilkan (TBM) di dataran rendah. Penelitian disusun menggunakan Rancangan Petak Terbagi (RPT) dengan dua faktor perlakuan. Klon sebagai

\footnotetext{
Dikomunikasikan oleh Mira Ariyanti

Ayuningsari, I., S. Rosniawaty, Y. Maxiselly, dan I.R.D. Anjarsari

Jurusan Agroteknologi Departemen Budidaya Tanaman

Fakultas Pertanian Universitas Padjadjaran

Korespondensi:
}

petak utama terdiri dari GMB 4, GMB 7, GMB 9, dan GMB 11. Konsentrasi Benzyl Amino Purine (BAP) sebagai anak petak terdiri dari $0 \mathrm{ppm}, 30$ ppm, 60 ppm, 90 ppm, dan 120 ppm. Hasil penelitian menunjukan adanya interaksi antara klon dan konsentrasi BAP terhadap pertambahan diameter batang pada 4 MSP. Konsentrasi BAP 60 ppm memberikan pengaruh terbaik terhadap diameter batang dan jumlah tunas pada 2 MSP. Klon GMB 4 menghasilkan jumlah tunas terbaik.

Kata kunci : TBM $\cdot$ Klon GMB $\cdot$ BAP

\section{Pendahuluan}

Produksi teh di Indonesia saat ini mengalami penurunan yang salah satunya disebabkan konversi lahan perkebunan teh menjadi lahan pertanian hortikultura (Rohmah dan Wachjar, 2015). Salah satu upaya untuk meningkatkan produksi teh dengan dilakukannya penanaman teh di dataran rendah. Penanaman teh di dataran rendah memiliki potensi yang besar untuk dikembangkan. Hal ini dikarenakan tanah pada dataran rendah umumnya termasuk ke dalam ordo Inceptisol yang merupakan ordo tanah dengan luas sebaran terbesar yaitu mencapai 70,52 juta ha atau sekitar 37,5\% dari luasan tanah di Indonesia (Djaenudin, 2008).

Penanaman teh di dataran rendah juga didukung dengan telah banyaknya klon teh unggul baru yang mampu tumbuh dan berproduksi baik di dataran rendah. Penggunaan jenis klon unggul penting karena pertumbuhan tanaman teh juga ditentukan oleh faktor genetik (Anjarsari, dkk., 2010). Klon-klon 
yang dikeluarkan oleh Pusat Penelitian Teh dan Kina (PPTK) Gambung seperti klon GMB 1 sampai dengan GMB 11 adalah beberapa klon unggul anjuran yang dibedakan kesesuaiannya untuk dataran rendah, sedang, dan tinggi (Permentan, 2014).

Pertumbuhan tanaman teh selain dipengaruhi faktor genetik dan faktor lingkungan, dipengaruhi pula oleh faktor budidaya. Budidaya tanaman teh sejak TBM (tanaman belum menghasilkan) bertujuan untuk menghasilkan pucuk dengan kualitas dan kuantitas yang optimal. Salah satu teknik budidaya pada TBM teh adalah centering. Centering bertujuan untuk menghasilkan tanaman yang memiliki kerangka dan percabangan yang ideal sehingga dapat memproduksi pucuk dengan optimal (Effendi, dkk., 2010). Tanaman teh setelah di-centering akan menumbuhkan tunas yang selanjutnya berperan dalam pembentukan bidang petik (Permentan, 2014).

Perluasan bidang petik juga dapat dilakukan dengan mengaplikasikan zat pengatur tumbuh (ZPT). ZPT sintetik dalam praktek usaha tani seringkali dinilai lebih murah dan praktis untuk diaplikasikan (Dinas Pertanian dan Tanaman Pangan Propinsi Jawa Barat, 2012). Salah satu jenis ZPT sintetik adalah Benzyl Amino Purine (BAP) yang termasuk ke dalam golongan sitokinin. Sitokinin adalah hormon tumbuhan yang berfungsi untuk merangsang pembelahan dan diferensiasi sel mitosis (Lindung dan Widyaiswara, 2014). Sel-sel yang membelah akan berkembang menjadi tunas, cabang, dan daun baru (Pratomo dkk., 2016).

Setiap klon memiliki respon yang berbeda terhadap konsentrasi BAP, sehingga perlu diketahui klon dan konsentrasi BAP yang tepat agar penanaman teh di dataran rendah dapat menghasilkan pertumbuhan yang optimal.

\section{Bahan dan Metode}

Percobaan dilaksanakan di Kebun Percobaan Ciparanje, Fakultas Pertanian, Universitas Padjajaran, Jatinangor yang berada pada ketinggian \pm $725 \mathrm{~m}$ dpl. Percobaan dilaksanakan pada bulan Desember 2016 sampai dengan bulan Maret 2017. Bahan yang digunakan adalah tanaman teh klon GMB 4, GMB 7, GMB 9, dan GMB 11 berumur 4 bulan. Bahan lainnya yaitu BAP, aquades, dan alkohol $70 \%$. Alat yang digunakan meliputi timbangan analitik, gunting setek, meteran, jangka sorong, Leaf area meter, hand sprayer, alat dokumentasi, dan alat tulis.

Percobaan dilaksanakan disusun menggunakan Rancangan Petak Terbagi (Split Plot Design) dengan 2 faktor perlakuan. Jenis klon (k) sebagai petak utama yang terdiri atas : $\left(\mathrm{k}_{1}\right)=$ GMB 4, $\left(\mathrm{k}_{2}\right)=$ GMB 7, $\left(\mathrm{k}_{3}\right)=$ GMB 9, dan $\left(\mathrm{k}_{4}\right)$ GMB 11. Konsentrasi BAP (b) sebagai anak petak terdiri atas $:\left(b_{0}\right)=0 \mathrm{ppm},\left(b_{1}\right)=30 \mathrm{ppm}$, $\left(b_{2}\right)=60$ ppm, $\left(b_{3}\right)=90$ ppm, $\left(b_{4}\right)=120 \mathrm{ppm}$. Terdapat 20 perlakuan dan setiap perlakuan diulang 2 kali, sehingga seluruhnya terdapat 40 satuan percobaan. Masing-masing satuan percobaan terdiri atas 2 tanaman sehingga jumlah seluruhnya 80 tanaman. Data yang diperoleh diuji normalitas Kolmogorov Smirnov. Data yang normal akan dilanjutkan dengan analisis ragam dengan uji $\mathrm{F}$ (Fisher) pada taraf 95\%. Data diuji lanjut dengan Uji Duncan apabila terdapat perbedaan yang nyata antar perlakuan.

Centering dilakukan dua minggu sebelum aplikasi BAP pertama. Teknis melakukan centering adalah dengan memenggal batang utama hingga tersisa 5 helai daun. BAP diaplikasikan menggunakan hand sprayer sesuai dengan konsentrasi perlakuan pada 0 Minggu Setelah Perlakuan (MSP), 2 MSP, 4 MSP, 6 MSP, 8 MSP, dan 10 MSP. Waktu aplikasi BAP adalah pada pukul 8.00 WIB.

Parameter pengamatan yang diuji adalah pertambahan tinggi tanaman, luas daun, jumlah tunas, dan pertambahan diameter batang. Pengamatan dilakukan pada 0 MSP sampai dengan 12 MSP.

\section{Hasil dan Pembahasan}

Pertambahan Tinggi Tanaman. Hasil analisis ragam menunjukkan bahwa tidak terdapat interaksi antara klon dan konsentrasi BAP terhadap pertambahan tinggi TBM teh. Jenis klon dan aplikasi BAP secara mandiri juga tidak memberikan pengaruh yang nyata terhadap pertambahan tinggi TBM teh (Tabel 1). Hal ini dikarenakan adanya penghilangan dominansi apikal, sehingga pertumbuhan terkonsentrasi ke pembentukan tunas lateral.

Centering yang dilakukan pada awal percobaan bertujuan untuk menghambat auksin sehingga sintesis sitokinin meningkat. Tanaman yang dipangkas ujung batangnya cenderung beralih melakukan pertumbuhan ke arah lateral, 
seperti pertumbuhan tunas lateral dan cabang. Hal ini diduga dikarenakan rasio sitokinin yang lebih besar dari auksin.

Belum berpengaruhnya aplikasi BAP dalam percobaan ini dikarenakan pemanjangan batang juga dipengaruhi oleh auksin (Darmanti, dkk., 2008). Auksin menyebabkan sel membesar dan memanjang dikarenakan auksin mengakibatkan potensial membran meningkat. Hal ini menyebabkan air masuk ke dalam sel secara osmosis dan meningkatkan plastisitas dinding sel yang memungkinkan sel untuk memanjang (Anjarsari, 2008).

Tabel 1. Pengaruh Mandiri Klon dan Konsentrasi BAP terhadap Pertambahan Tinggi Tanaman Teh Belum Menghasilkan.

\begin{tabular}{|c|c|c|c|c|c|c|}
\hline \multirow{3}{*}{ Perlakuan } & \multicolumn{6}{|c|}{$\begin{array}{c}\text { Rata-Rata Pertambahan Tinggi } \\
\text { Tanaman }(\mathrm{cm})\end{array}$} \\
\hline & 2 & 4 & 6 & 8 & 10 & 12 \\
\hline & MSP & MSP & MSP & MSP & MSP & MSP \\
\hline \multicolumn{7}{|l|}{ Klon Teh } \\
\hline $\mathrm{k}_{1}=\mathrm{GMB} 4$ & 0,23 & 0,45 & 0,56 & 0,72 & 0,86 & 1,15 \\
\hline $\mathrm{k}_{2}=\mathrm{GMB} 7$ & 0,34 & 0,65 & 0,85 & 1,10 & 1,31 & 2,06 \\
\hline $\mathrm{k}_{3}=\mathrm{GMB} 9$ & 0,42 & 0,69 & 0,83 & 1,12 & 1,33 & 1,51 \\
\hline $\mathrm{k}_{4}=\mathrm{GMB} 11$ & 0,19 & 0,38 & 0,60 & 0,78 & 0,92 & 1,19 \\
\hline \multicolumn{7}{|c|}{ Konsentrasi BAP } \\
\hline $\mathrm{b}_{0}=0 \mathrm{ppm}$ & 0,26 & 0,52 & 0,68 & 0,91 & 1,13 & 1,34 \\
\hline $\mathrm{b}_{1}=30 \mathrm{ppm}$ & 0,25 & 0,48 & 0,59 & 0,91 & 1,10 & 1,40 \\
\hline $\mathrm{b}_{2}=60 \mathrm{ppm}$ & 0,31 & 0,57 & 0,73 & 0,95 & 1,04 & 1,73 \\
\hline $\mathrm{b}_{3}=90 \mathrm{ppm}$ & 0,36 & 0,54 & 0,76 & 0,90 & 1,09 & 1,43 \\
\hline $\mathrm{b}_{4}=120 \mathrm{ppm}$ & 0,29 & 0,60 & 0,78 & 0,98 & 1,16 & 1,46 \\
\hline
\end{tabular}

Keterangan : angka pada kolom yang sama menunjukkan tidak berbeda nyata menurut Uji $F$ pada taraf $95 \%$.

MSP $=$ Minggu setelah perlakuan

Luas Daun. Hasil analisis ragam menunjukkan tidak ada interaksi antara klon dan konsentrasi BAP terhadap luas daun TBM teh. Hasil analisis ragam menunjukkan bahwa jenis klon dan aplikasi BAP secara mandiri belum mempengaruhi secara nyata terhadap luas daun tanaman teh pada 12 MSP (Tabel 2).

Luas daun berperan dalam mendukung tanaman membentuk fotosintat yang selanjutnya akan ditranslokasikan untuk pembentukan organ vegetatif lainnya (Paramita, dkk., 2014). Perbedaan yang tidak nyata dalam parameter luas daun diduga karena energi yang ada lebih diarahkan untuk menstimulasi pertumbuhan tunas lateral. Pengaruh aplikasi sitokinin terhadap luas daun tanaman dikotil umumnya baru dapat terlihat setelah diaplikasikan berulang kali dan efeknya kecil (Siswiarti, 2002).
Tabel 2. Pengaruh Mandiri Klon dan Konsentrasi BAP terhadap Luas Daun Tanaman Teh Belum Menghasilkan pada 12 MSP.

\begin{tabular}{cc}
\hline \hline Perlakuan & $\begin{array}{c}\text { Luas Daun }\left(\mathrm{cm}^{2}\right) \\
12 \text { MSP }\end{array}$ \\
\hline Klon Teh & \\
$\mathrm{k}_{1}=$ GMB 4 & 688,10 \\
$\mathrm{k}_{2}=$ GMB 7 & 975,57 \\
$\mathrm{k}_{3}=$ GMB 9 & 555,75 \\
$\mathrm{k}_{4}=$ GMB 11 & 1014,71 \\
\hline Konsentrasi BAP & \\
$\mathrm{b}_{0}=0$ ppm & 807,80 \\
$\mathrm{~b}_{1}=30$ ppm & 761,79 \\
$\mathrm{~b}_{2}=60$ ppm & 1173,80 \\
$\mathrm{~b}_{3}=90 \mathrm{ppm}$ & 692,25 \\
$\mathrm{~b}_{4}=120$ ppm & 607,02 \\
\hline \hline
\end{tabular}

Keterangan : angka pada kolom yang sama dengan perlakuan yang sama menunjukkan tidak berbeda nyata menurut Uji F pada taraf $95 \%$

MSP = Minggu setelah perlakuan

Aplikasi BAP 60 ppm $\left(b_{2}\right)$ cenderung menghasilkan daun yang lebih luas. Hal ini menunjukkan bahwa sitokinin mampu meningkatkan luas daun tanaman. Sitokinin merangsang perluasan daun yang merupakan hasil dari pembesaran sel (Lindung dan Widyaiswara, 2014).

Jumlah Tunas. Hasil analisis ragam menunjukkan tidak ada interaksi antara klon dan konsentrasi BAP terhadap jumlah tunas TBM teh. Hasil analisis ragam yang tercantum pada Tabel 3 menunjukkan bahwa jenis klon berpengaruh nyata terhadap jumlah tunas pada 12 MSP namun tidak menunjukkan pengaruh nyata pada 2, 4, 6, 8, dan 10 MSP. Aplikasi BAP berpengaruh nyata terhadap jumlah tunas pada 2 MSP, namun tidak menunjukkan pengaruh nyata pada 4, 6, 8, 10, dan 12 MSP.

Konsentrasi BAP $60 \mathrm{ppm}\left(\mathrm{b}_{2}\right)$ menunjukkan hasil terbaik dibandingkan perlakuan lainnya pada $2 \mathrm{MSP}$, tetapi tidak berbeda nyata dengan kontrol (Tabel 3). Menurut Pratomo, dkk., (2016), sitokinin berfungsi untuk merangsang pembelahan sel tanaman. Sel-sel tersebut selanjutnya akan berkembang menjadi tunas, cabang, dan daun. Hal ini sesuai dengan hasil penelitian Siswiarti (2002) bahwa aplikasi BAP 60 ppm pada tanaman teh menghasilkan (TM) mampu meningkatkan jumlah tunas yang muncul serta mempercepat pertumbuhan tunas lateral. Hasil penelitian Kathiravetpillai dan Kulasegaram (1981) juga menunjukkan bahwa aplikasi BAP 75 ppm pada tanaman teh mampu menghasilkan tunas dengan jumlah yang lebih banyak. 
Tabel 3. Pengaruh Mandiri Klon dan Konsentrasi BAP terhadap Jumlah Tunas Tanaman Teh Belum Menghasilkan.

\begin{tabular}{|c|c|c|c|}
\hline \multirow[b]{2}{*}{ Perlakuan } & \multicolumn{3}{|c|}{ Rata-Rata Jumlah Tunas } \\
\hline & $2 \mathrm{MSP}$ & 4 MSP6 MSP8 MSP $\begin{array}{c}10 \\
\text { MSP }\end{array}$ & $\begin{array}{c}12 \\
\text { MSP }\end{array}$ \\
\hline \multicolumn{4}{|l|}{ Klon Teh } \\
\hline $\mathrm{k}_{1}=\mathrm{GMB} 4$ & $1,35 \mathrm{a}$ & 3,55 a 5,65 a 6,65 a 7,70 a & $8,35 \mathrm{~b}$ \\
\hline $\mathrm{k}_{2}=\mathrm{GMB} 7$ & 0,95 a & 2,45 a 3,35 a 4,15 a 4,75 a & $4,95 \mathrm{a}$ \\
\hline $\mathrm{k}_{3}=\mathrm{GMB} 9$ & $0,40 \mathrm{a}$ & 2,80 a 4,10 a 4,35 a 4,75 a & $4,90 \mathrm{a}$ \\
\hline$\underline{\mathrm{k}_{4}=\mathrm{GMB} 11}$ & $1,70 \mathrm{a}$ & 4,95 a 6,20 a 6,45 a 7,05 a & $7,20 \mathrm{a}$ \\
\hline \multicolumn{4}{|c|}{ Konsentrasi BAP } \\
\hline $\mathrm{b}_{0}=0 \mathrm{ppm}$ & $1,56 \mathrm{ab}$ & 3,63 & $6,19 \mathrm{a}$ \\
\hline $\mathrm{b}_{1}=30 \mathrm{ppm}$ & $0,50 \mathrm{a}$ & 5 a 6,06 a & $6,31 \mathrm{a}$ \\
\hline $\mathrm{b}_{2}=60 \mathrm{ppm}$ & $2,38 \mathrm{~b}$ & 4,38 a 5,63 a 5,94 a 6,69 a & $6,94 \mathrm{a}$ \\
\hline $\mathrm{b}_{3}=90 \mathrm{ppm}$ & $0,25 \mathrm{a}$ & 3,88 a 5,69 a 6,31 a 6,81 a & $7,06 \mathrm{a}$ \\
\hline $\mathrm{b}_{4}=120 \mathrm{ppm}$ & $0,81 \mathrm{a}$ & 2,81 a 3,94 a 4,50 a 4,75 a & $5,25 \mathrm{a}$ \\
\hline
\end{tabular}

Keterangan : angka yang diikuti oleh huruf yang sama pada kolom yang sama menunjukkan tidak berbeda nyata menurut Uji F pada taraf 95\%

MSP = Minggu setelah perlakuan

Aplikasi BAP selanjutnya tidak berpengaruh nyata pada 4, 6, 8, 10, dan 12 MSP. Menurut Sitanggang, dkk., (2015), pengaruh yang tidak nyata dari aplikasi ZPT disebabkan proses fisiologis tanaman telah berjalan dengan baik sehingga ZPT tidak memberikan pengaruh yang berarti. Hal ini dikarenakan sifat ZPT hanya sebagai biostimulan dalam proses fisiologis tanaman.

Klon tanaman menunjukkan pengaruh yang nyata terhadap jumlah tunas pada 12 MSP. Jumlah tunas terbaik diperoleh pada $\mathrm{k}_{1}$ (GMB 4) yang berbeda nyata terhadap perlakuan lainnya, namun tidak berbeda nyata terhadap $\mathrm{k}_{4}$ (GMB 11). Hal ini diduga karena klon GMB 4 memiliki keunggulan yaitu pertumbuhan setelah pangkas cepat, serta memiliki ketahanan terhadap hama dan penyakit yang sangat baik (Pusat Penelitian Teh dan Kina, 2016).

Pertambahan Diameter Batang. Penelitian ini menunjukkan bahwa aplikasi BAP berpengaruh nyata terhadap pertambahan diameter batang pada 2 MSP, namun tidak menunjukkan pengaruh nyata pada 4, 6, 8, 10, dan 12 MSP. Klon belum berpengaruh nyata terhadap pertambahan diameter batang TBM teh (Tabel 4). Hasil analisis ragam menunjukkan terdapat interaksi antara klon dan konsentrasi BAP terhadap pertambahan diameter batang pada 4 MSP (Tabel 5).

Aplikasi BAP menunjukkan pengaruh yang nyata terhadap pertambahan diameter batang pada 2 MSP. Pemberian BAP dengan konsentrasi 60 ppm $\left(b_{2}\right)$ menghasilkan pertambahan diameter batang terbaik tetapi tidak berbeda nyata dengan pemberian BAP kosentrasi 120 ppm $\left(b_{4}\right)$. Hal ini menunjukkan bahwa sitokinin BAP mampu meningkatkan pertambahan diameter batang pada 2 MSP.

Tabel 4. Pengaruh Mandiri Klon dan Konsentrasi BAP terhadap Pertambahan Diameter Batang Tanaman Teh Belum Menghasilkan.

\begin{tabular}{lccccc}
\hline \multirow{2}{*}{ Perlakuan } & \multicolumn{5}{c}{ Rata-Rata Pertambahan Diameter } \\
\cline { 2 - 6 } & 2 MSP & 6 MSP & 8 MSP & 10 MSP & $12 M S P$ \\
\hline Klon Teh & & & & & \\
$\mathrm{k}_{1}=$ GMB 4 & $0,45 \mathrm{a}$ & $0,82 \mathrm{a}$ & $0,95 \mathrm{a}$ & $0,86 \mathrm{a}$ & $1,15 \mathrm{a}$ \\
$\mathrm{k}_{2}=$ GMB 7 & $0,19 \mathrm{a}$ & $0,46 \mathrm{a}$ & $0,60 \mathrm{a}$ & $1,31 \mathrm{a}$ & $2,06 \mathrm{a}$ \\
$\mathrm{k}_{3}=$ GMB 9 & $0,45 \mathrm{a}$ & $0,62 \mathrm{a}$ & $0,82 \mathrm{a}$ & $1,33 \mathrm{a}$ & $1,51 \mathrm{a}$ \\
$\mathrm{k}_{4}=$ GMB 11 & $0,21 \mathrm{a}$ & $0,54 \mathrm{a}$ & $0,70 \mathrm{a}$ & $0,92 \mathrm{a}$ & $1,19 \mathrm{a}$ \\
\hline Konsentrasi BAP & & & & \\
$\mathrm{b}_{0}=0$ ppm & $0,22 \mathrm{a}$ & $0,44 \mathrm{a}$ & $0,58 \mathrm{a}$ & $1,04 \mathrm{a}$ & $1,34 \mathrm{a}$ \\
$\mathrm{b}_{1}=30$ ppm & $0,14 \mathrm{a}$ & $0,63 \mathrm{a}$ & $0,75 \mathrm{a}$ & $1,09 \mathrm{a}$ & $1,40 \mathrm{a}$ \\
$\mathrm{b}_{2}=60$ ppm & $0,47 \mathrm{~b}$ & $0,85 \mathrm{a}$ & $1,04 \mathrm{a}$ & $1,04 \mathrm{a}$ & $1,73 \mathrm{a}$ \\
$\mathrm{b}_{3}=90 \mathrm{ppm}$ & $0,19 \mathrm{a}$ & $0,53 \mathrm{a}$ & $0,69 \mathrm{a}$ & $1,09 \mathrm{a}$ & $1,43 \mathrm{a}$ \\
$\mathrm{b}_{4}=120$ ppm & $0,31 \mathrm{ab}$ & $0,59 \mathrm{a}$ & $0,77 \mathrm{a}$ & $1,16 \mathrm{a}$ & $1,46 \mathrm{a}$ \\
\hline \hline
\end{tabular}

Keterangan : angka yang diikuti oleh huruf yang sama pada kolom yang sama menunjukkan tidak berbeda nyata menurut Uji F pada taraf $95 \%$ MSP = Minggu setelah perlakuan

Tabel 5. Pengaruh Interaksi Klon dan Konsen-trasi BAP terhadap Pertambahan Diameter Batang (mm) Tanaman Teh Belum Menghasilkan pada 4 MSP.

\begin{tabular}{cccccc}
\hline \hline & \multicolumn{5}{c}{ Konsentrasi BAP (B) } \\
\cline { 2 - 6 } Klon (K) & $\mathrm{b}_{0=0}$ & $\mathrm{~b}_{1}=30$ & $\mathrm{~b}_{2}=60$ & $\mathrm{~b}_{3}=90$ & $\mathrm{~b}_{4}=120$ \\
& $\mathrm{ppm}$ & $\mathrm{ppm}$ & $\mathrm{ppm}$ & $\mathrm{ppm}$ & $\mathrm{ppm}$ \\
\hline $\mathrm{k}_{1}=$ & $0,33 \mathrm{a}$ & $0,47 \mathrm{a}$ & $1,08 \mathrm{a}$ & $0,45 \mathrm{a}$ & $0,95 \mathrm{a}$ \\
GMB 4 & $\mathrm{A}$ & $\mathrm{A}$ & $\mathrm{B}$ & $\mathrm{A}$ & $\mathrm{B}$ \\
$\mathrm{k}_{2}=$ & $0,11 \mathrm{a}$ & $0,46 \mathrm{a}$ & $0,42 \mathrm{a}$ & $0,34 \mathrm{a}$ & $0,39 \mathrm{a}$ \\
$\mathrm{GMB} 7$ & $\mathrm{~A}$ & $\mathrm{~A}$ & $\mathrm{~A}$ & $\mathrm{~A}$ & $\mathrm{~A}$ \\
$\mathrm{k}_{3}=$ & $0,38 \mathrm{a}$ & $0,94 \mathrm{a}$ & $0,71 \mathrm{a}$ & $0,27 \mathrm{a}$ & $0,30 \mathrm{a}$ \\
GMB 9 & $\mathrm{A}$ & $\mathrm{B}$ & $\mathrm{AB}$ & $\mathrm{A}$ & $\mathrm{A}$ \\
$\mathrm{k}_{4}=$ & $0,56 \mathrm{a}$ & $0,20 \mathrm{a}$ & $0,47 \mathrm{a}$ & $0,43 \mathrm{a}$ & $0,22 \mathrm{a}$ \\
GMB 11 & $\mathrm{A}$ & $\mathrm{A}$ & $\mathrm{A}$ & $\mathrm{A}$ & $\mathrm{A}$ \\
\hline \hline
\end{tabular}

Keterangan: Angka yang diikuti oleh huruf kecil yang sama pada kolom yang sama menunjukkan tidak berbeda nyata menurut Uji F pada taraf $95 \%$ Angka yang diikuti oleh huruf capital yang sama pada baris yang sama menunjukkan tidak berbeda nyata menurut Uji F pada taraf $95 \%$

Peran sitokinin dalam meningkatkan pertambahan diameter batang berhubungan dengan fungsinya dalam menstimulasi pembelahan sel. Schmulling (2004) menyatakan bahwa sitokinin berperan dalam pembelahan sel pada jaringan kambium, meristem tunas apikal, dan daun muda. Menurut Darmanti (2008), peningkatan kadar sitokinin dapat memacu 
penyempurnaan berkas pembuluh antara tunas lateral dan batang tanaman. Batang tanaman kemudian akan bertambah diameternya pada saat inisial fusiform kambium membentuk xilem dan floem sekunder. Terbentuknya jaringan pembuluh sekunder ini yang berperan terhadap pertambahan diameter batang berkayu.

Hasil analisis pada Tabel 4 menunjukkan bahwa peningkatan konsentrasi BAP di atas 60 ppm cenderung menghasilkan pertumbuhan diameter batang yang lebih rendah. Menurut Paramita, dkk. (2014), konsentrasi ZPT yang terlalu tinggi dapat menghambat pertumbuhan sementara konsentrasi yang terlalu rendah juga tidak akan berpengaruh terhadap pertumbuhan tanaman.

Tabel 5 menunjukkan bahwa adanya pengaruh yang berbeda dari konsentrasi BAP pada klon yang sama, namun pengaruh klon adalah sama pada setiap konsentrasi BAP yang diberikan. Klon GMB $4\left(\mathrm{k}_{1}\right)$ memberikan respon yang lebih baik terhadap konsentrasi BAP 60 ppm $\left(b_{2}\right)$ dan 120 ppm $\left(b_{4}\right)$, sementara untuk $k_{3}(G M B$ 9) respon yang lebih baik dihasilkan terhadap konsentrasi BAP 30 ppm ( $\left.b_{1}\right)$ dan 60 ppm ( $\left.b_{2}\right)$. Interaksi antara klon dan konsentrasi BAP pada diameter batang dapat terjadi karena pertumbuhan dan perkembangan tanaman adalah merupakan hasil interaksi antara faktor genetik dan lingkungan. Faktor genetik dalam penelitian ini adalah klon, sedangkan faktor lingkungan adalah BAP yang diaplikasikan sebagai hormon eksogen. Gabungan faktor genetik dan faktor lingkungan secara bersama-sama akan menampilkan karakter tanaman. Gen bertanggung jawab terhadap sintesis protein, enzim, dan hormon (Harahap, 2012). Menurut Ramadan, dkk. (2016), hormon endogen dan hormon eksogen berinteraksi dalam mempengaruhi metabolisme tanaman.

\section{Kesimpulan}

1. Terdapat pengaruh konsentrasi BAP terhadap jumlah tunas dan pertumbuhan diameter batang tanaman teh belum menghasilkan di dataran rendah pada 2 MSP yaitu pada konsentrasi $60 \mathrm{ppm}$.

2. Terdapat interaksi antara konsentrasi BAP dan klon terhadap pertambahan diameter batang tanaman teh belum menghasilkan di dataran rendah pada 4 MSP. Interaksi terbaik yaitu pada klon GMB 4 dengan konsentrasi BAP 60 ppm.

\section{Daftar Pustaka}

Anjarsari, I. R. D. 2008. Peranan dan Fungsi Fitohormon bagi Pertumbuhan Tanaman. Tersedia Online pada : repository.unpad. ac.id. Diakses pada bulan Juni 2017

Anjarsari, I. R. D., S. Rosniawaty, dan M. Ariyanti. 2010. Pengaruh Kombinasi Pupuk $\mathrm{P}$ dan Kompos terhadap Pertumbuhan Tanaman Teh (Camellia sinensis (L.) O. Kuntze) Belum Menghasilkan Klon Gambung 7. Tersedia Online pada : repository. unpad.ac.id. Diakses September 2016

Darmanti, S., N. Setiari, dan T. D. Romawati. 2008. Perlakuan Defoliasi untuk Meningkatkan Pembentukan dan Pertumbuhan Cabang Lateral Jarak Pagar (Jatropha curcas). Tersedia Online pada : ejournal. undip.ac.id. Diakses pada bulan Mei 2-17

Dinas Pertanian dan Tanaman Pangan Propinsi Jawa Barat. 2012. Mengenal Berbagai Macam Zat Pengatur Tumbuh (ZPT). Tersedia Online pada : http://distan. jabarprov.go.id. Diakses pada bulan September 2016

Djaenudin, D. 2008. Perkembangan penelitian sumber daya lahan dan kontribusinya untuk mengatasi kebutuhan lahan pertanian Indonesia. Jurnal Litbang Pertanian 27 (4). Bogor

Effendi, D.S., M. Syakir, M. Yusron, dan Wiratno. 2010. Budidaya dan Pascapanen Teh. Pusat Penelitian dan Pengembangan Perkebunan. Tersedia Online pada : http:// perkebunan.litbang.pertanian.go.id. Diakses pada bulan September 2016

Harahap. 2012. Fisiologi Tumbuhan BAB IV Pertumbuhan dan Perkembangan. Tersedia Online pada : digilib.unimed.ac.id. Diakses pada bulan Mei 2017

Kathiravetpillai, A., and S. Kulasegaram. 1981. Effect of some growth regulators on growth and apical dominance of young tea (Camellia sinensis) (L.) O. Kuntze) - Effect of indole acetic acid, benzyl adenine and ethrel. Tea Q. 50 (3) : 138-146. Tersedia Online pada : dl.nsf.ac.lk. Diakses pada bulan Mei 2017

Lindung dan Widyaiswara. 2014. Teknologi Aplikasi Zat Pengatur Tumbuh (ZPT). BPP Jambi. Tersedia Online pada : http://www.bppjambi.info. Diakses pada bulan September 2016 
Paramita, G., D. Indradewa, dan S. Waluyo. 2014. Pertumbuhan bibit tujuh klon teh (Camellia sinensis (L.) Kuntze) PGL dengan pemberian bahan mengandung hormon tumbuh alami. Vegetalika 3 (2) : 1-12. Tersedia Online pada : jurnal.ugm.ac.id. Diakses pada bulan Mei 2017

Permentan. 2014. Pedoman Teknis Budidaya Teh yang Baik. Tersedia Online pada : http://perundangan.pertanian.go.id. Diakses pada bulan September 2016

Pratomo, B., C. Hanum, dan L. A. P. Putri. 2016. Pertumbuhan okulasi tanaman karet (Hevea brassiliensis Muell arg.) dengan tinggi penyerongan batang bawah dan benzilaminopurin (BAP) pada pembibitan polibeg. Jurnal Pertanian Tropik 2 (13) : 119-123. Tersedia Online pada : jurnal.usu.ac.id. Diakses bulan Mei 2017

Pusat Penelitian Teh dan Kina, Gambung, Jawa Barat. 2016. Deskripsi Klon Teh.

Ramadan, V. R., N. Kendarini, dan S. Ashari. 2016. Kajian pemberian zat pengatur tumbuh terhadap pertumbuhan stek tanaman buah naga (Hylovereus costaricensis).
Jurnal Produksi Tanaman 4 (3) : 180-186

Rohmah, N., dan A. Wachjar. 2015. Pengelolaan pemangkasan tanaman teh (Camellia sinensis (L.) O. Kuntze) di Wonosobo. Buletin Agrohorti 3 (1) : 79-86. Tersedia Online pada : journal.ipb.ac.id. Diakses Mei 2017

Schmulling, T. 2004. Cytokinin. In Encyclopedia of Biological Chemistry (Eds. Lennarz, W., Lane, M.D.). Academic Press/Elsevier Science. Tersedia Online pada : www. angenetik.fu-berlin.de. Diakses Mei 2017

Siswiarti, S. 2002. Pengaruh Berbagai Konsentrasi dan Frekuensi Pemberian Zat Pengatur Tumbuh (Sitokinin dan Adenin) terhadap Pemecahan Dormansi dan Pertumbuhan Pucuk Tanaman Teh Produksi (Camellia sinensis L.). Tesis Program Pascasarjana, Universitas Sumatera Utara

Sitanggang, A., Islan, dan S.I. Saputra. 2015. Pengaruh pemberian pupuk kandang ayam dan zat pengatur tumbuh giberelin terhadap pertumbuhan bibit kopi arabika (Coffea arabica L.). JOM Faperta Vol 2 No. 1. Tersedia di jom.unri.ac.id. Diakses bulan Mei 2017 